\title{
PROGRAMOWANIE SANACJI PRZESTRZENI WIEJSKIEJ AUTORSKIE MECHANIZMY PLANISTYCZNE NA RZECZ ZRÓWNOWAŻONEGO KSZTALTOWANIA OBSZARÓW WIEJSKICH
}

\begin{abstract}
Zarys treści: $\mathrm{W}$ pierwszej części artykułu autorzy diagnozują problemy procesu planowania przestrzennego w Polsce wynikające $\mathrm{z}$ obowiązującego systemu prawnego oraz identyfikują ich efekty w przestrzeni wiejskiej. W drugiej części skupiają się na prezentacji trzech wątków badawczych, stanowiących propozycję aplikacyjnych metod wdrażanych eksperymentalnie do procesu planistycznego, bazując na doświadczeniach praktycznych. W podsumowaniu konstruują listę rekomendacji dotyczących programowania sanacji zagospodarowania obszarów wiejskich.
\end{abstract}

Słowa kluczowe: planowanie przestrzenne, obszary wiejskie, strategiczne rezerwy inwestycyjne, metoda FAST.

\section{Pesymistyczny obraz planowania przestrzennego na obszarach wiejskich}

Proces przemian społeczno-gospodarczych zainicjowany w 1989 roku odcisną swoje piętno także w sferze gospodarowania przestrzenią, ale zdecydowana większość źródeł jest zgodna co do tego, że skutki transformacji w wielu obszarach dotyczących jakości kształtowania środowiska nie mogą być ocenione pozytywnie. Już 4 lata po wprowadzeniu Ustawy z dnia 27 marca 2003 roku o planowaniu i zagospodarowaniu przestrzennym ${ }^{1}$, H. Izdebski, A. Nielicki i I. Zachariasz (2007) zanalizowali mankamenty systemu prawnego utrwalające tę sytuację, ale ich wnioski zasadnie nie koncentrowały się wyłącznie na ramach prawnych, które przecież należy rozumieć jako służebne wobec merytorycznych wymogów planowania przestrzennego. Dostrzegli oni, że w redagowaniu dokumentów na szczeblu gminnym pojawia się wiele niespójności, że brakuje zintegrowania dokumen-

\footnotetext{
${ }^{1}$ Dz.U., 2017, poz. 1073, z późn. zm.
} 
tów poruszających odmienne aspekty gospodarowania zasobami gminnymi, lecz opracowywanymi przez na przykład inne wydziały urzędów, niekoordynowane wzajemnie (Izdebski i in. 2007). Już wówczas wiele rozwiązań systemowych sprawiało wrażenie fasadowych, jak choćby partycypacja społeczna, którą autorzy oceniają zdecydowanie jako miejsce artykułowania partykularnych interesów poszczególnych użytkowników przestrzeni, a nie wypracowywania zgodnej i akceptowanej przez lokalną społeczność formy kompromisu między interesem publicznym a prywatnym. Problem partykularyzmu wzmacniany jest bowiem przez sądowe orzecznictwo, płytko rozpoznające zasadnicze cele zagospodarowania przestrzennego, ignorujące prymat zagadnień zdefiniowanych już w art. 1 Ustawy z dnia 27 marca 2003 roku o planowaniu i zagospodarowaniu przestrzennym.

W 2011 roku raport Najwyższej Izby Kontroli podsumowywał kondycję zagospodarowania przestrzennego jako niesatysfakcjonującą: „sfera planowania przestrzennego w dalszym ciągu jest nieuporządkowana, co nie sprzyja zapewnieniu ładu przestrzennego i tworzeniu warunków do zrównoważonego rozwoju kraju" (NIK 2011: 8). Raport powoływał się na skompilowaną w 2007 roku i uzupełnioną w 2008 roku diagnozę Ministerstwa Budownictwa stwierdzającą znaczące niedostatki systemu prawnego utrudniającego skuteczne tworzenie ładu przestrzennego postulowanego w ustawowej preambule. W raporcie krytycznie ustosunkowano się do zbadanych bezpośrednio praktyk tworzenia dokumentów szczebla lokalnego wykazujących, zdaniem autorów, liczne nieprawidłowości i w związku z tym nieskuteczność formowania zrównoważonego środowiska.

Warto zauważyć, że wiele procedur diagnozowania przyczyn obecnego stanu zagospodarowania przestrzennego opiera się na badaniach ilościowych, na gromadzonych danych parametrycznych, zwłaszcza w kwestii wypełnienia obowiązków wynikających z prawa (np. powierzchnia opracowanych miejscowych planów zagospodarowania przestrzennego, aktualność opracowań planistycznych) nałożonych na gminy. O ile badania ilościowe są bezwzględnie konieczne i obiektywizują postrzeganie pewnych wybranych problemów dotyczących planowania przestrzennego, o tyle dysproporcja związana z niedostatkiem lub brakiem badań jakościowych o jasno ustalonych kryteriach powiązanych z wartościami definiowanymi w preambule ustawy powoduje, że w raporcie umykają niektóre najistotniejsze zjawiska, które w sposób trwalszy deprecjonują przestrzeń i środowisko przyrodnicze. Zauważają to choćby P. Śleszyński z zespołem (2012), trafnie diagnozując poważny problem w nieprawidłowo moderowanej presji inwestycyjnej. Stwierdzają, że szczególnie negatywne zjawiska uwidaczniają się w obszarach rolniczych, wiejskich. Użytkownicy przestrzeni są wyposażeni przez organy państwowe lub samorządowe w ugruntowaną orzecznictwem koncepcję nienaruszalności własności oraz domniemanego przywileju. Wyraża się to jakże często w działaniach samorządowych kolegiów odwoławczych, dopatrujących się prawa do zabudowy i spełnienia warunków ustawowych także tam, gdzie udo- 
wodnienie ich nie wynika z parametrów przestrzennych środowiska, lecz z permisywnej wykładni prawa. Zgodnie z tą wykładnią oczekuje się od gmin kreatywnej gimnastyki intelektualnej pozwalającej na niepożądane w środowisku inwestycje lub przekształcenia. W związku z tym podmioty świadome cykliczności społeczno-politycznego podłoża wyłaniania lokalnej władzy, rozgrywają partykularny interes forsując urbanizację w miejscach, w których usankcjonowanie tego procesu jest co najmniej dyskusyjne (Raport o ekonomicznych... 2013).

Mija już piętnaście lat funkcjonowania ustawy, a zarówno Ministerstwo Infrastruktury i Budownictwa, jak Najwyższa Izba Kontroli dostrzegają bardzo poważną skalę problemów planistycznych. W dokumencie ministerialnym, stanowiącym materiał informacyjny dla parlamentarzystów, przygotowany w maju 2016 roku, wreszcie w sposób syntetyczny napisano, że:

„Jednym z najpoważniejszych skutków braku dostatecznie silnego umocowania planowania przestrzennego w systemie realizacji polityk państwa jest błędne postrzeganie prawa swobodnej zabudowy jako elementu przynależnego do każdej nieruchomości - podczas, gdy możliwość zabudowania podlega reglamentacji publicznoprawnej, a prawo zabudowy przypominać powinno prawo uzyskiwane na mocy zezwolenia" (MIiB 2016: 1-2).

Najwyższa Izba Kontroli prezentuje, w tym samym 2016 roku, raport o stanie gospodarowania przestrzenią, w którym też dostrzega zjawiska wpływające negatywnie na jakość stanu zagospodarowania przestrzeni i jej funkcjonowania. Słabością jest destrukcyjne oddziaływanie decyzji o warunkach zabudowy, niezdolność do wykształcenia spójności między dokumentami strategicznymi dla lokalnych samorządów (studium uwarunkowań i kierunków zagospodarowania przestrzennego - SUiKZP). Nie przestrzega się nawet instrumentalnego obowiązku zachowywania zasad dobrego sąsiedztwa, spójności tkanki zurbanizowanej (NIK 2016: 13, 20, 32-33). Problemów jest tak dużo, że podważają one skuteczność całego systemu planowania przestrzennego, co choć nie wyrażone explicite, ujawnia się w skali postulowanych zmian i usprawnień. Celnie puentuje to B. Kolipiński (2014), analizując 25-letnią ewolucję myślenia o systemie gospodarki przestrzennej i stwierdzając, że planowanie jest bodaj najgorszym komponentem reformy samorządowej, tym który jest źródłem mechanizmów dopuszczających powstawanie zabudowy poza regulacjami planistycznymi, rozwiązań de facto konfliktogennych, nieefektywnych i korupcjogennych. Z powyższym w przeważającej mierze trafnym osądem nie zgodzić się należy tylko w końcowej konkluzji, w której autor ocenił, że mimo wszystko przestrzeń w Polsce staje się „ładniejsza” - być może dzieje się tak w miastach, w pewnej mierze także w centralnych partiach miejscowości, jednak w istocie system planowania działa przeciw prawidłowemu rozwojowi, w szczególności obszarów wiejskich. Taki obraz wyłania się z wielu dostępnych dokumentów badających jakość przestrzeni, tak przekrojowych, jak fragmentarycznych. Te wnioski jednak zgodnie wypływają 
z przywołanych już wcześniej dokumentów ministerialnych oraz raportów NIK, wykorzystywanych przez najwyższe struktury w państwie. Taki stan rozwiązań dotyczących przestrzeni utrudnia precyzyjne definiowanie ładu, nie wskazując prawidłowych praktyk planistycznych i nie odnosząc się krytycznie do orzecznictwa, często sprzecznego z intencją ustawodawcy i wykładnią, co skutkuje dewastacją krajobrazów i tak znacznym rozproszeniem struktur zurbanizowanych, że zacierają się granice obszarów otwartych, niezabudowanych z obszarami zabudowanymi.

Polska wieś doświadcza, ale i jest generatorem problemów przestrzennych, które prowadzą do obniżania jakości środowiska, w którym funkcjonują lokalne społeczności. Problemy tła społeczno-gospodarczego obejmują: utrudnione uwarunkowania funkcjonowania produkcji rolnej, a także warunki jej opłacalności, niestabilność determinant prawnych i systemowych widoczną w częstotliwości i jakości zmian prawa i wynikających z tego konsekwencji (nieustające fluktuacje na rynkach, europejska polityka jako narzędzie kryptoregulacji podaży i popytu, niestabilność okresów przejściowych między okresami finansowania itp.), dewastujące żniwo polityki przestrzennej epoki komunizmu oraz okresu transformacji (teoretycznie przywracającej liczne swobody, w rzeczywistości sankcjonującej anarchię lub partykularyzm), rujnującą formę prywatyzacji sektora rolno-spożywczego oraz brak wypracowanych mechanizmów stabilizujących rynek rolny (por. np. Kowalik 2000, 2001, 2007; Górecki 2015; Zagóra-Jonszta 2017), wreszcie polityczne przyzwolenie na traktowanie prawa zabudowy jako rozdawanego przywileju dla gremiów politycznych szczebla samorządowego (ABW 2005: 14-17, 20).

Trzeba jednak dostrzec i te problemy, które nie zostały wytworzone odgórnie lub które stanowiłyby czynniki głównie zewnętrzne, bowiem znaczną część złej jakości przestrzeni wsi zawdzięcza się zjawiskom wytworzonym tamże (przez mieszkańców bądź decydentów lokalnych). Są to między innymi:

- brak ograniczeń terenowych w zakresie przekształcania obszarów rolnych na obszary zabudowy - mechanizmy dotąd nieskuteczne,

- rabunkowy sposób gospodarowania terenami rolnymi - krótkoterminowa wielokrotnie wyższa efektywność ekonomiczna sprzedaży nieruchomości względem wysiłku związanego z prowadzeniem działalności rolnej,

- egoizm właścicieli gruntów - ekstremalnie szkodliwy społecznie (rozpraszanie infrastruktury, deprecjacja wartości nieruchomości wskutek nadpodaży, syndrom „łatwego pieniądza”),

- naciski polityczne niskiego szczebla na realizację partykularnych potrzeb z naruszeniem wartości środowiskowych, kulturowych itp.,

- kształtowanie struktur szkodliwych i pogłębiających problemy przestrzenne - układy ulicowe, mieszanie typów zabudowy, brak działań wspierających jakość krajobrazu. 
Kompleksowe, skoordynowane działania zmieniające system są niezbędne, by uzyskać system jakościowo odmienny, generujący statystycznie znacznie większą ilość korzystnych regulacji przestrzennych, dostosowanych do realiów inwestycyjnych, ale traktujących pryncypialnie długoterminowy interes publiczny. To jednak zadanie dość efemeryczne, a w zasięgu codziennej praktyki urbanistycznej naprawianie przestrzeni wiejskiej, wpływającej przecież także na gospodarczą kondycję wsi, może się zacząć stopniowo, przez drobne w swej skali usprawnienia metodyczne i aplikacyjne.

\section{Budowanie ramy metodycznej i puli doświadczeń}

Skala problemów, których istnienie determinuje niską jakość przestrzeni wsi, wywołuje także znaczące koszty zarówno w ujęciu finansowym, jak i społecznym (por. np. Borkowski 2011; Szwajdler i in. 2013). Całkiem znaczny udział w eskalacji tych problemów mają pośrednio decyzje planistyczne skutkujące przecież zobowiązaniami gmin do realizacji infrastruktury technicznej. Ogromny wpływ, często o negatywnym charakterze, ma niespójność instrumentarium, jakie zapewnia system prawny, a nade wszystko jego upodmiotowienie (por. np. Barełkowski 2009; Czarnik 2010). Zamiast służyć rozwiązywaniu konkretnych problemów, prawo zdaje się egzystować niezależnie od celu, do którego zostało powołane, formując własne standardy nie tylko sprzeczne ze zdrowym rozsądkiem, ale i logiką, np. sposób interpretacji pojęcia sąsiedztwa i dotyczące tego, rozszerzające orzecznictwo, w istocie opierające się nie na wykładni, lecz właśnie interpretacji, deprecjonujące obiektywne lub obiektywizowane kryteria formowania zagospodarowania przestrzennego (por. Woźniak 2015). Wszystkich czynników rysujących niezbyt korzystny obraz uwarunkowań przesądzających o jakości przestrzeni podmiejskiej i wiejskiej naturalnie nie sposób wymienić, istotną komplikację w tej kwestii wprowadza też oddziaływanie indywidualnych dla danego miejsca i danej ewaluacji czynników.

Złożoność zagadnień rozstrzyganych w regulacjach przestrzennych zaciera też hierarchię ważności problemów, a niekiedy także zdolność do przeprowadzenia prawidłowej diagnozy, gdy z zebranych lokalnie parametrów przestrzennych wykazuje się nadmierną liberalność ustaleń lokalnych regulacji przestrzennych dla tych parametrów, o czym mówi choćby C. Brzeziński (2013), uznając swobodę zabudowy terenów i wbudowaną w system za zachętę do odwoływania się do zapisów pozwalających $\mathrm{w}$ istocie zignorować plany miejscowe albo przez fakt sparaliżowania ich procedur, albo przez odwołanie się do decyzji o warunkach zabudowy. $Z$ tych przesłanek niektórzy badacze wyciągają niekiedy mylne wnioski, obarczając odpowiedzialnością detaliczne ustalenia ustawowe, których znaczenie ujawnia się przecież dopiero w translacji uchwał na fizyczne, a nie występujące wcześniej, organizacyjne działanie inwestorów (Hajduk, Baran 2013). 
To nie nadmierna szczegółowość zapisów planistycznych, o ile założyć ich poprawne skonstruowanie pod względem celowym i użytkowym, jest jednym z wiodących utrudnień w uzyskaniu ładu przestrzennego, tylko konstrukcja systemu ułatwiającego uproszczoną ścieżkę prawną tam, gdzie urbanista ma niewiele do powiedzenia i nie analizuje kontekstu przestrzennego (decyzja o warunkach zabudowy). Plan miejscowy nie jest przecież narzędziem umożliwiającym inwestorom działania budowlane, bo te mogłyby być zaspokojone decyzjami o warunkach zabudowy - niestety w praktyce często jego rola sprowadzana jest do funkcji trudniejszej do przeprowadzenia i nieco bardziej kompleksowej decyzji o warunkach zabudowy dla większego areału, choć ustawodawca sugeruje relację odwrotną - substytucyjny charakter decyzji względem planu miejscowego.

Potrzeba uleczenia przestrzeni, tytułowej sanacji, czyli poprawy jej jakości, zachęca do holistycznej analizy problemu. Systemowe spojrzenie na kwestię planowania przestrzennego powinno uwzględniać nie tylko odgórne struktury koordynujące działania (poszczególnych komórek administracyjnych, poszczególnych dokumentów), statystykę pokrycia terytorium kraju opracowaniami planów miejscowych (często przyjmowaną przez wielu badaczy jako kryterium oceny stanu zagospodarowania przestrzennego, nieadekwatnie do rzeczywistych ustaleń ładu przestrzennego jako nadrzędnej wartości w zagospodarowaniu przestrzennym), ale koncentrować się nad prawidłowo diagnozowanymi cechami przestrzeni, w kontekście ich indywidualnej, unikalnej charakterystyki. Rozwiązanie problemów przestrzennych polskiej wsi nie może bazować wyłącznie na odgórnych (ang. top-down) ustaleniach. Czynniki rzeczywiście odpowiedzialne za realne skutki (rzeczywistą jakość przestrzeni) muszą być budowane oddolnie (ang. bottom-up), nie z perspektywy regionu, województwa, tym bardziej kraju, a regulacje nadrzędne powinny je koordynować, ale nie paraliżować.

Głównym celem artykułu jest prezentacja rozwiązań aplikacyjnych mających wesprzeć proces sanacji przestrzeni wiejskiej, funkcjonujących i skutecznych na poziomie lokalnym, w tym dotyczących przede wszystkim sposobu użytkowania terenów przez indywidualnych użytkowników, sposobu budowania realiów transakcji związanych z nieruchomościami itp. jako źródła prawidłowej kalibracji systemu, także, a może przede wszystkim, w obszarze dopuszczalnych ustaleń prawnych. Autorzy skupiają się na prezentacji wątków badawczych, stanowiących propozycję aplikacyjnych metod wdrażanych eksperymentalnie do procesu planistycznego, bazując na doświadczeniach praktycznych.

Kośćcem założeń programowych prezentowanych doświadczeń są metody eksperymentalne, bazujące na tezach formułowanych za pośrednictwem prototypowych opracowań planistycznych o rozmaitej funkcjonalności, poddawanych falsyfikowaniu w procesie rzeczywistej implementacji - użytkowania przez jednostki samorządu terytorialnego. 
Prowadzone badania, z których $\mathrm{w}$ niniejszej pracy prezentuje się wybrane wnioski adekwatne do wybranej tematyki, zawężonej na potrzeby określonego problemu, są jedynie kulminacją procesu poznawczego, poprzedzone badaniami literaturowymi, waloryzacyjnymi, wsparte argumentacją logiczną i próbą wielokryterialnej, wieloaspektowej oceny środowiskowej (Barełkowski 2015; Barełkowski i in. 2016a), zasilającej konstruowanie strategii interwencyjnych w konkretnych obszarach (Barełkowski 2012). W newralgicznych z punktu widzenia gmin miejscach, wprowadzane są także rozszerzone metody partycypacyjne, znacznie wykraczające poza ramy określone w ustawie, gdyż te skromne wymogi prawne w istocie nie generują prawdziwego uczestnictwa i wielopodmiotowej refleksji nad środowiskiem (Barełkowski 2005, 2008). Większość z nich jest związana $\mathrm{z}$ testowaniem i usprawnianiem formuły metody P.R.S. nie tylko w opracowaniu planów miejscowych, ale i w szeregu studiów i dokumentów zależnych, takich jak prognozy środowiskowe, finansowe, ekofizjografie, oceny aktualności dokumentów planistycznych, a ostatnio po wejściu w życie zmian Ustawy o planowaniu $i$ zagospodarowaniu przestrzennym wywołanych Ustawa $z$ dnia 9 października 2015 roku o rewitalizacji², także bilansów terenów przeznaczonych pod zabudowę (Barełkowski, Barełkowska 2003).

Badania pozwalające w tym opracowaniu formułować autorskie konkluzje dotyczą zakresu lokalnego, konkretnych rozwiązań dla konkretnych gmin, m.in. wielkopolskich gmin Rokietnica i Oborniki. Postulują wprowadzanie rozwiązań w istniejącym stanie relacji między elementami planowania przestrzennego, pomimo wygenerowanych przez nie problemów omówionych wyżej. Pomyślane są jako propozycje do natychmiastowego zastosowania w praktyce, a ich poziom innowacyjności - o ile można w ogóle użyć tego określenia - odnosi się przede wszystkim do skonstruowania metodycznego i merytorycznego komponentu, bowiem opracowania planistyczne nie mają siły sprawczej, działają wyłącznie jako odniesienie dla inwestorów, użytkowników przestrzeni (mieszkańców) bądź też dla administracji lokalnej.

\section{Zderzenie z realiami - trzy wątki badawcze}

Działania ujęte w procesie wypełniania postulatów zintegrowanych działań oddolnych (realizowanych przez planistę) obejmowały trzy zasadnicze wątki prób usprawniania efektów - przezwyciężania w lokalnych aplikacjach tych utrudnień, które wynikając z ograniczeń aktualnego systemu stoją w opozycji do głoszonych w jego ramach pryncypiów. Wątki te określono jako współbieżne mechanizmy: prawne, planistyczne i analityczne. Równocześnie występujące w aktualnym systemie sprzeczności hierarchiczne, na przykład niezdolność prawa do służenia rozwiązywaniu problemów przez to prawo postulowanych, wymogły wdrożenie

\footnotetext{
${ }^{2}$ Dz.U., 2017, poz. 1023, z późn. zm.
} 
kroków proceduralnych niemających konstruktywnych konsekwencji dla obsługiwanego środowiska, lecz koniecznych, by cele stawiane przed danym opracowaniem mogły być zrealizowane.

Przykładem alogiczności funkcjonującego systemu jest choćby koncepcja monitoringu przestrzeni widziana jako proces interwałowy, przeprowadzany co najmniej raz na cztery lata, a więc punktowy w czasie. Monitoring nie jest w ustawie wpisany w pulę dokumentów inicjujących proces planistyczny, a analizy wynikające z bilansów terenów zabudowy (wymóg ustawowy: art. 10, ust. 1, pkt 7 Ustawy z dnia 27 marca 2003 roku o planowaniu i zagospodarowaniu przestrzennym), pozbawione modelowej hipotezy stawianej przez planistę (stan po zaplanowanej transformacji) są bezproduktywne. Nie dostarczają zrozumienia skutków przemian, które mogłyby się pojawić, gdyby zadanie analiz potraktować bardziej jako element prognostyki. Brak uświadomienia celu działań planistycznych oraz osiąganych wartości wynikających z kierunków (sposoby i narzędzia wpływające na jakość założeń programowych, ideowych) nie pozwala interpretować wyników analiz stanu istniejącego w kontekście założeń gmin co do ich rozwoju przestrzennego.

Cele opracowań planistycznych ujawniają się zazwyczaj dopiero w momencie wdrożenia dokumentu, a monitoring prowadzony w rytmie kadencyjności sprowadza się najczęściej do odnotowania spełnienia obowiązku nałożonego przez prawo, bez refleksji nad jakością opracowań (art. 32, ust. 1 Ustawy z dnia 27 marca 2003 roku o planowaniu i zagospodarowaniu przestrzennym). Widać to też w praktyce oceny gospodarowania przestrzenią w dokumentach NIK, gdzie ocena jakościowa - jeśli jest - najczęściej dotyka warsztatu, a nie sposobu potraktowania samej przestrzeni jako podmiotowego, nieodnawialnego zasobu (ryc. 1).

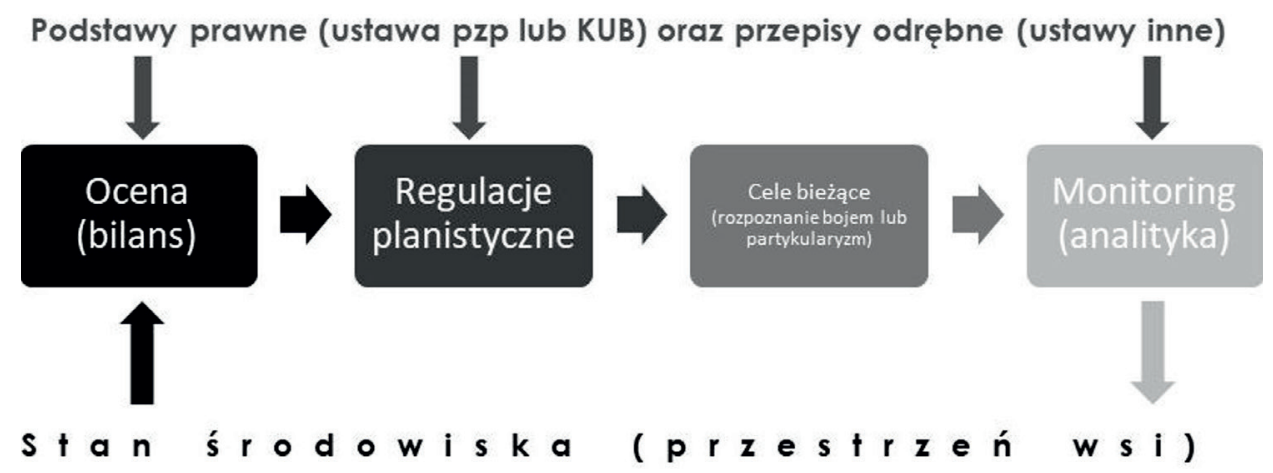

Objaśnienia: ustawa pzp - Ustawa o planowaniu i zagospodarowaniu przestrzennym; KUB - Kodeks urbanistyczno-budowlany - projekt

Ryc. 1. Fragmentacja procesu planistycznego na szczeblu lokalnym 
W praktyce taka lokalizacja monitoringu - weryfikacji zachodzących w przestrzeni przekształceń, zarówno w ujęciu ilościowym, jak i jakościowym, rozdzielałaby obowiązek prowadzenia analiz przestrzennych skoncentrowanych na waloryzacji (a nie na określaniu potencjału w zakresie możliwości zabudowy) od opracowań w rodzaju studium uwarunkowań i kierunków zagospodarowania przestrzennego (SUiKZP) bądź miejscowych planów zagospodarowania przestrzennego (MPZP). Potwierdzeniem tego jest obserwacja praktyki urbanistycznej, sposobu, w jaki profesjonalne zespoły optymalizują własne zachowania ekonomiczne, realizując zasadę adekwatnej pracy za adekwatną płacę, czyli de facto ograniczania kosztów związanych z niewymaganymi ustawą czynnościami.

Na podstawie dostępnych obserwacji krytycznych, zarówno autorskich, jak i pochodzących od innych badaczy (wymienionych wyżej w tekście), wydaje się uprawniona hipoteza o konieczności rozpoczynania procedur planistycznych nie od określenia jakie przeznaczenie terenu, lecz jaki stan terenu jest oczekiwanym skutkiem działań w ramach zagospodarowania przestrzennego. Takie rozpoznanie funkcji celu w całym procesie planistycznym, zagubione w pofragmentowanej strukturze ustawowej, pozwala na reorganizację i, przy zachowaniu zgodności z przepisami ustawowymi oraz niestety dla praktyków, rozszerzeniem zakresu obowiązków spoczywających na planiście, na podjęcie próby poprawy jakości opracowywanych projektów (ryc. 2).

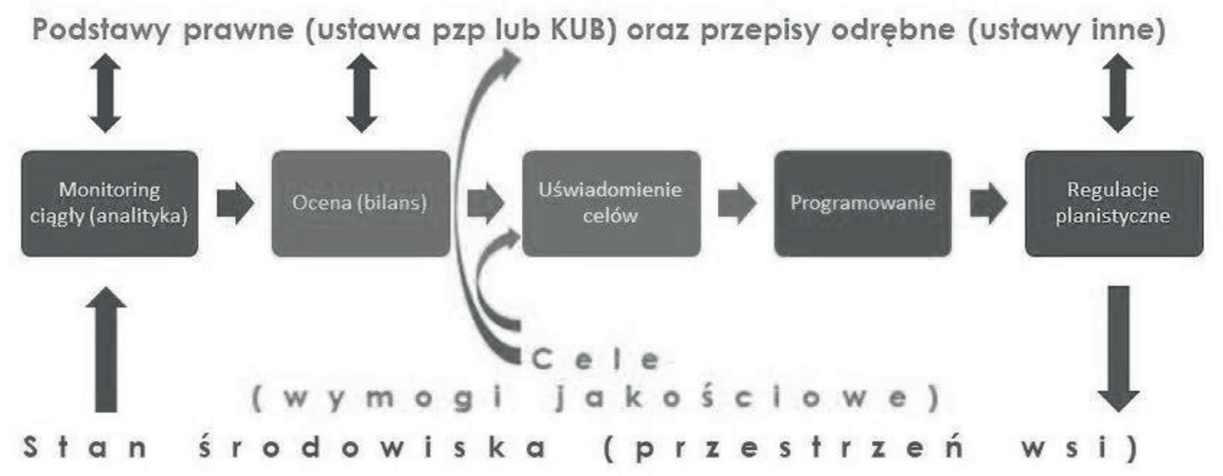

Ryc. 2. Postulowana korekta procesu planistycznego na szczeblu lokalnym Źródło: opracowanie własne

Wspomniane mechanizmy, prawne, planistyczne i analityczne, muszą być wzajemnie skorelowane. W prezentowanych niżej wybranych aplikacjach, które można z ostrożności określać jako quasi-eksperymenty (ze względu na ograniczoną zdolność do ponawiania kroków proceduralnych ograniczonych wymogami wdrożenia praktycznego oraz ograniczoną przez strony trzecie zdolnością do poprawy parametrów jakościowych rozwiązań), oznaczało to uznanie procesu planistycznego za proces kreacyjny uporządkowany celowo: idea - planowanie 
- projektowanie - planowanie - realizacja, z istotnym rozróżnieniem, w którym termin projektowanie oznacza próbę zasymulowania rzeczywistego zagospodarowania z wszystkimi wynikającymi z tego konsekwencjami i interakcjami (nie sposób tu dokładnie opisać znaczenia powyższego stwierdzenia, można poddać jednak przykładową analogię - projektowanie pozwala zobaczyć konsekwencje, np. liberalnych zapisów dotyczących geometrii dachów lub lokalizacji zabudowy wzdłuż ulicy i zbadać, jakie konsekwencje ma to dla spójności i jakości przestrzeni, testować próby „złamania ograniczeń”).

Narzędziowa, służebna rola przepisów prawa skłaniała do wypracowania takich form prawnych opracowywanych prototypów, by były zgodne z aktami prawnymi, zasadami techniki prawodawczej, ale równocześnie realizowały odmienne rozwiązania wzmacniające jakość regulacji planistycznych.

Zaczynając od wskazania mechanizmów o naturze prawnej warto zauważyć odmienność działań na poziomie SUiKZP oraz MPZP. W przypadku pierwszego, z oczekiwaną 15-letnią perspektywą funkcjonowania zapisów od momentu przyjęcia określonych rozwiązań, problem dezaktualizacji ustaleń dla obszarów newralgicznych wydaje się jednym z powszechnych i bardzo dotkliwych. Propozycją umożliwiającą uelastycznienie zapisów studium, które nie mają charakteru prawa miejscowego i mogą w związku z tym oferować alternatywne ścieżki rozwojowe, stało się planowanie scenariuszowe. Nie jest ono potrzebne w obszarach o cechach przewidywalnych, w których potencjalna dynamika zmian funkcjonalnych lub związanych z intensywnością wykorzystania nie jest wysoka, lecz w najistotniejszych lokalizacjach zamrażanie funkcji lub parametrów określonych w SUiKZP okazuje się być bezproduktywnym bagażem dla gmin.

Opracowane na potrzeby planowania przestrzennego $\mathrm{w}$ ramach metody P.R.S. planowanie scenariuszowe odbiega nieco od opisu prezentowanego przez P. Schoemakera (1995), choćby w tym, że podaje warianty zbliżone co do funkcji, ale odmienne typologicznie. Scenariusze rozwojowe zaplanowano dla terenów określonych jako:

$\rightarrow$ SRI - strategiczne rezerwy inwestycyjne (profile scenariuszowe) - najistotniejsze dla struktury przestrzennej gminy tereny o dużym potencjale w zakresie wielofunkcyjnego wykorzystania, w szczególności w przypadku niemożności lub niepraktyczności jednoznacznego określenia kierunku rozwojowego (ryc. 3),

$\rightarrow$ SRZZ - strategiczne rezerwy dla zabudowy zorganizowanej - tereny rolne, które warunkowo mogą być przekształcane na obszary zurbanizowane w przypadku pełnego uzbrajania podziemnego i wykształcenia układów drogowych, a które pozwalają lokalnemu samorządowi na kontrolowanie przeznaczenia, gdyż jego zmiana ustalona jest w studium warunkowo (przeznaczenie rolnicze jest domyślnym, zmiana tego przeznaczenia wymaga podjęcia przez radę gminy uchwały kierunkującej). 
Pierwsze opracowanie tego typu zostało zrealizowane w latach 2007-2011 dla podpoznańskiej gminy Rokietnica i od tego czasu funkcjonuje skutecznie, umożliwiając obecnie wypełnienie najistotniejszego miejsca w gminie - centrum największej wsi, w ramach strategii rekonfiguracji (Barełkowski 2014; Wojtyra 2017). Narzędzie niestety traci swoją elastyczność w momencie opracowywania planu miejscowego, zgodnie z wymogami prawnymi musi być to bowiem zapis jednoznaczny, a ustawodawca do dziś nie potrafi zapisać możliwości scenariuszowego rozwiązywania problemów przestrzennych.

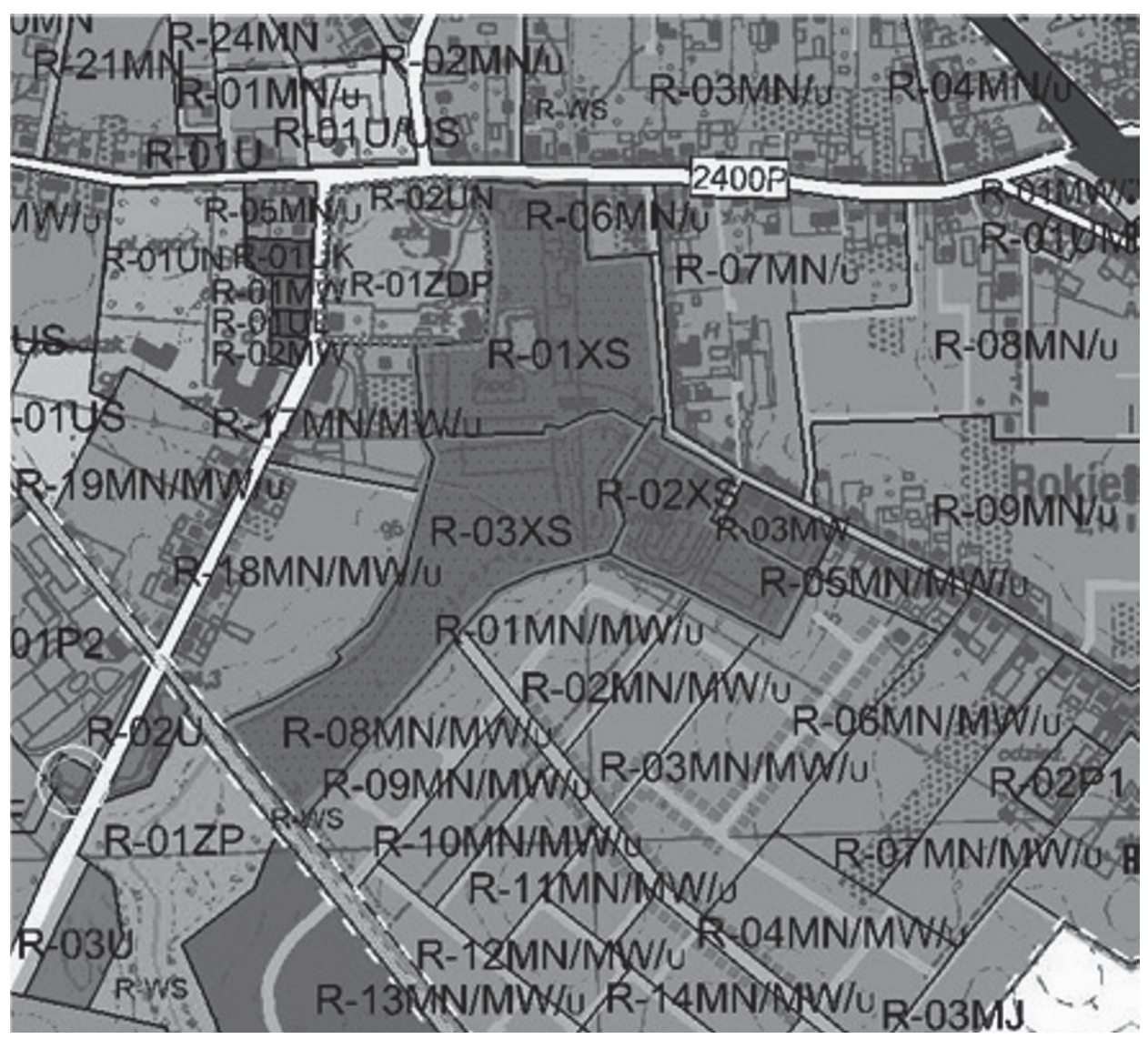

Ryc. 3. Fragment SUiKZP gminy Rokietnica z zastosowaniem przeznaczenia pod Strategiczne Rezerwy Inwestycyjne (tereny R-01XS, R-02XS, R-03XS)

Źródło: Biuro Projektowe Armageddon

W planie miejscowym udaje się natomiast wprowadzać inne mechanizmy. Przykładem tego jest ochrona wartości krajobrazowych, kulturowych. Rysująca się coraz silniej deprecjacja przestrzeni wiejskiej spowodowała przecież reakcję 
ustawodawcy, który dostrzegając konieczność rozszerzenia repertuaru restrykcji przestrzennych wprowadził w ustawie o rewitalizacji zmianę w kształcie dopuszczalnych regulacji planów miejscowych, w szczególności umocowując typologie, rozwiązania materiałowe, kolorystykę, nawet wzorcowe formy. Te elementy, wdrażane przez członków zespołu badawczego jeszcze w ubiegłej dekadzie, kontynuowane do dziś, uległy wzmocnieniu po zmianach ustawy o planowaniu i zagospodarowaniu przestrzennym literalnie wymieniających możliwość ustalania tych parametrów - nadal jednak uprawnienia urbanistów w tym względzie są nadmiernie ograniczane.

W sferze postulatywnej, niemożliwej do obecnego wdrożenia, pozostają dwa istotne zagadnienia. Jedno $\mathrm{z}$ nich to umożliwienie realizacji konkursów urbanistycznych i architektonicznych jako czynników determinujących automatycznie ustalenia zagospodarowania, co pozwoliłoby zdyskontować formułę konkursu jako wyłaniania najlepszego rozwiązania w drodze konfrontacji idei i symulowanych alternatyw. Drugie to fundamentalne założenie korygujące największą patologię systemu planowania przestrzennego w Polsce, to jest powiązanie decyzji o warunkach zabudowy ze SUiKZP. Nie ma tu bowiem sprzeczności czy prawnych dylematów - decyzja o warunkach zabudowy pozostaje prawnym substytutem planu miejscowego, zatem w intencji ustawodawcy (wyciąganej wprost z zapisów ustawy) organy orzekające $w$ sprawach przestrzeni powinny dostrzegać konieczność zgodności decyzji z SUiKZP. Prosta korekta prawa okazuje się jednak pozbawiać samorządy określonych przywilejów i pozamerytoryczne względy przyczyniają się do dalszego pustoszenia przestrzeni.

W obszarze mechanizmów planistycznych zarówno SRI jak SRZZ (skróty wyjaśnione wyżej w tekście) implikują szereg działań projektowych, symulujących skutki oddziaływania. Te wielowariantowe analizy nie są jednak traktowane jako wypracowywanie modelu optymalnego, lecz wypracowywanie modeli równoległych, spośród których wybór nastąpi w odpowiednim momencie rozwoju gminy, niemożliwym do przewidzenia i zarazem określenia warunków brzegowych, koniunktury, kondycji finansowej, możliwości realizacji strategicznych zadań ponadlokalnych itp.

Powyższe dociekania, konieczne ze względu na praktyczny charakter eksperymentów prowadzonych „na żywo”, na rzeczywistych procedurach, wykazały ogromne znaczenie predykcji, a zwłaszcza analityki zaprzęganej do wspomagania procesów decyzyjnych. Niemniej, pozostając przy aktywności planistycznej (bezpośrednim działaniu kreacyjnym), wymienić należy wdrożenie granic obszaru urbanizacji (w pewnej mierze analogii dla urban growth boundary), a także katalogu dopuszczalnych typologii, stanowiącego pochodną analiz wiążących owe typologie z profilem użytkowników, czyli np. relacją między określonym typem zabudowy a określonymi potencjalnymi nabywcami tych nieruchomości i demograficzną dynamiką gminy. 
Rozpoznanie form przyrostu wskaźnika zagospodarowania, a zatem efektywności prowadzenia polityki przestrzennej przez gminę Rokietnica na wybranych obszarach, skłoniło do uzupełnienia arsenału narzędzi o model analizy FAST (Barełkowski 2015; Barełkowski i in. 2016b). Punktem wyjścia do nich są analizy demograficzne, nie tylko odzwierciedlające liczbowo procesy społeczne, ale przede wszystkim powiązanie tendencji użytkowania konkretnych przestrzeni z konkretnymi grupami. $Z$ tej zależności generowane są bowiem parametry opisujące chłonność teoretyczną i chłonność rzeczywistą, niezbędne do określenia w ramach procedury analitycznej, w której nie można zignorować przyszłych, choć niepewnych transformacji.

Ocena wielokryterialna stanu aktualności SUiKZP i planów miejscowych (Barełkowski in. 2016a) oraz bazujący na jej ustaleniach bilans terenów przeznaczonych na zabudowę, który umownie zespół badawczy nazywa wielokryterialną analizą chłonności realizowaną w ramach metody P.R.S./FAST Matrix, nie mogą się ograniczać do intuicyjnego, eksperckiego zebrania dostarczonych danych terenowych - muszą dynamicznie prezentować ewentualne fluktuacje form użytkowania i powiązanych z tym ruchów użytkowników przestrzeni. Pozwala to ocenić skutki koncentracji i integracji albo w przeciwnym przypadku rozproszenia i segregacji wiejskich struktur osadniczych. Złożony algorytm reprezentujący procesy rzeczywiste $\mathrm{w}$ przestrzeni badane i precyzowane są $\mathrm{w}$ ramach parametrów związanych z przyrostem zabudowy, takich jak:

- chłonność obowiązująca i projektowana,

- gęstość rzeczywista i gęstość projektowana,

- wskaźnik urbanizacji obowiązujący i wskaźnik urbanizacji projektowany,

- efektywność urbanizacji.

Odmiennym wątkiem, którego zasygnalizowanie widzi się jako konieczne, jest zagadnienie zróżnicowania typów planów w zależności od podejmowanej problematyki. Mowa tu na przykład o planach sankcjonujących wyłącznie zmiany legislacyjne, czyli aktualizacja dotychczas obowiązujących aktów. Powinno to przecież przebiegać znacznie prościej, sprawniej. Odrębnie traktować należałoby plany ochronne, a odrębnie plany in cruda radice, jeszcze inaczej plany dotykające obszarów cennych pod względem dziedzictwa historycznego - ale wszystko to w jednym zintegrowanym systemie, a nie jak to dziś ma miejsce, w kilku różnych ustawach (Barełkowski i in. 2013).

Skąpość powyższego opisu, podyktowana ograniczoną objętością tekstu, skłania do uwypuklenia tego, co w prowadzonych wdrożeniach jest powtarzalnym i kluczowym motywem działania. To swoista pętla logicznych rozpoznań - hipotetycznego programowania przestrzeni, jej form i funkcji, ale też generowanych w ten sposób interakcji. Okazuje się, że obserwowane substandardowe praktyki urbanistyczne wynikają nie tylko z niedostatecznego oparcia procesu decyzyjnego na adekwatnej puli danych analitycznych, ale też na zaniedbaniu czy wręcz 
zaniechaniu elementów symulujących przyszłe wykorzystanie terenu z próbą określenia parametrów infrastruktury, ruchu kołowego, form związanych z zagospodarowaniem i wreszcie lokalizowanych przestrzennie ludzkich zachowań. Zarówno ocena stanu przestrzeni (a nie tylko ocena aktualności zapisów SUiKZP, jak prymitywizuje to ustawa), analizy, jak i rozwiązania projektowe muszą mieć na uwadze przyszły stan zagospodarowania, w tym jakościowe alternatywy dla interakcji z terenami sąsiednimi lub innymi powiązanymi funkcjonalnie.

\section{Dyskusja o potrzebie sanacji - wnioski i ograniczenia}

Naprawa środowiska przestrzennego to proces długotrwały, o ogromnej inercji, w którym nie sposób całkowicie wyeliminować emergentnych czynników deformujących. Programowanie planistyczne zintegrowane z projektowaniem i planowaniem, a także z procesem oceny i analizy traktowanej jako jeden, nierozłączny wątek podbudowujący uzasadnienie decyzji planistycznych, to zdaniem autorów klucz do kreatywnego - a więc pozwalającego na uwypuklanie w zwykle bezdusznych procedurach wątku kulturowego, tożsamościowego - procesu sanacji przestrzeni wiejskiej.

Zaproponowane rozwiązania koncentrują się na obecnie obowiązującym systemie, w którym proces decyzyjny pozostaje silnie odseparowany od skutków wywołanych w przestrzeni, niedostatecznie chroniąc interes publiczny oraz wartości przestrzenne. Są zatem uniwersalnym remedium podatnym na ewentualne zmiany ram prawnych. Zmiany te $\mathrm{w}$ dotychczas prezentowanym kształcie Kodeksu urbanistyczno-budowlanego, choć w części podejmowały wątek niedostatków systemu planistycznego w Polsce, pozostawały niesatysfakcjonujące i niejako zapatrzone w nieco archaiczną koncepcję linearnego procesu od zamysłu do decyzji. Jednym z przykładów takiego zrutynizowanego podejścia jest brak dostrzegania znaczenia perspektywy detalu - a zatem znaczenia rozwiązań architektonicznych, skali percypowanej przez użytkownika przestrzeni. Skala ta wykracza bowiem daleko poza oddziaływanie, potocznie widziane jako dbanie o estetykę przestrzeni. Estetyka jest bowiem tylko wartością dodaną, a czynniki ją warunkujące budowane przez skuteczne rozwiązania architektoniczne są konieczne do tego, by wysiłek planistów miał szansę przynieść pozytywny rezultat.

Dotychczasowe propozycje realizowane na szczeblu krajowym nie przezwyciężyły już istniejących problemów, które nagromadziły się przez lata rabunkowej gospodarki przestrzenią i są nieodwracalne. Brakuje strategii leczenia tego, co już dziś jest substandardowe, a przecież zignorowanie tych zjawisk nie pozwoli nowym regulacjom osiągnąć wysokiego poziomu efektywności. Projekt Kodeksu urbanistyczno-budowlanego nie promował rozwiązań scenariuszowych, uelastyczniających funkcjonowanie SUiKZP, nie wprowadzał też rozwiązań honoru- 
jących wartości przestrzenne, w tym architektoniczne i urbanistyczne, np. przez sankcjonowanie przeprowadzanych konkursów, a nawet właściwej kolejności prowadzenia kroków zmierzających do podjęcia ustaleń przestrzennych.

Skutki prowadzonych eksperymentów z rozwiązaniami planistycznymi nasuwają dość oczywiste wnioski możliwe do realizowania na szczeblu indywidualnych praktyk bądź to zespołów planistycznych, bądź gmin. Potrzeba tu jednak woli i zrozumienia dla zwiększonego wysiłku po stronie wszystkich interesariuszy takich procesów. Autorzy na podstawie doświadczeń praktycznych, wdrożeniowych formułują zatem sześć wniosków poddawanych pod dyskusję odbiorcy:

1. Istnieje potrzeba wyższego stopnia integracji regulacji przestrzennych różnych szczebli, jednak ze zrozumieniem nie tylko nadrzędności np. planów wojewódzkich, ale ze świadomością, że studia i plany miejscowe lepiej, szczegółowiej rozpoznają materię lokalną (dokumenty powinny być zatem bardziej zintegrowane niż stricte hierarchiczne).

2. Kluczową kwestią jest wprowadzenie stałego, ciągłego monitoringu (a nie tylko raz na kadencję władz samorządowych).

3. Istotą jest wprowadzenie oceny uwarunkowań przestrzennych i kierunków, wspartej bogatą, wielowątkową analityką, zanim przystąpi się do wykonania zmian SUiKZP.

4. Ocena powinna prowadzić do sprecyzowania (i wyeksplikowania) celów działań przestrzennych, a ustawa powinna definiować narzędzia regulacyjne, tak by cele dawało się realizować (np. ochrona krajobrazu, ograniczenia materiałowe, ograniczenia jakościowe, typologiczne odnośnie architektury, wprowadzenie obowiązku stosowania elementów kulturowo utrwalonych - ciągłość kulturowa itp.).

5. Partycypacja powinna koncentrować się także na publicznym zdefiniowaniu celów - w tej sferze procedura planistyczna unikałaby paraliżu spowodowanego przez ewentualne kontestowanie rozwiązań.

6. Regulacje planistyczne powinny każdorazowo wynikać z holistycznego ujęcia obejmującego szeroką perspektywę, ale równocześnie uznawać odmienne cele planowania w obszarach o odmiennej charakterystyce (można to zilustrować przez przykład planów ochronnych, które powinny mieć odrębnie skonstruowaną procedurę, uproszczoną, by szybciej doprowadzać do skutecznej osłony wrażliwych obszarów; inny sposób precyzowania ustaleń w SUiKZP - jako dokumentu szczegółowego). 


\section{Literatura}

Agencja Bezpieczeństwa Wewnętrznego (ABW), 2005, Korupcja w Polsce - próba analizy zjawiska, Raport Agencji Bezpieczeństwa Wewnętrznego, Warszawa.

Barełkowski R., 2005, Web-based social participation in the process of town planning, [w:] Duarte J.P., Ducla-Soares G., Zita Sampaio A. (red.), Digital Design: The Quest for New Paradigms, Technical University of Lisbon, Lisbon: 557-564.

Barełkowski R., 2008, Web-based support for social participation and education in planning procedures, [w:] Muylle M. (red.), Architecture in „Computro”, University College of Antwerpen, College of Design Sciences, The Higher Institute of Architectural Sciences, Antwerp: 823-828.

Barełkowski R., 2009, Prawo - czynnik instrumentalizacji przestrzeni, Międzynarodowa Konferencja Naukowa, Międzyuczelniana: „Krajobrazy Europy. Gospodarka planowa czy generowanie chaosu?”, Panel 1, „Krajobraz jako celowy czy ,uboczny produkt' działalności architekta i planisty”: III konferencja z cyklu „Oblicza równowagi”, Politechnika Wrocławska, Wrocław.

Barełkowski R., 2012, The Edge of the [dis]Order, [w:] Pacetti M., Passerini G., Brebbia C.A., Latini G. (red.), The Sustainable City VII. Urban Regeneration and Sustainability, „WIT Transactions on Ecology and the Environment”, 155, Wessex Institute of Technology, WIT Press, Southampton \& Boston: 759-770.

Barełkowski R., 2014, Strategies for identity of sustainable suburbs, [w:] Marchettini N., Brebbia C.A., Pulselli R., Bastianoni S. (red.), The Sustainable City IX. Urban Regeneration and Sustainability, „WIT Transactions on Ecology and the Environment”, 191, Wessex Institute of Technology, WIT Press, Southampton \& Boston: 667-679.

Barełkowski R., 2015, FAST Matrix - depicting the time-related aspect of urban development, [w:] Brebbia C.A., Flores-Escobar W.F. (red.), The Sustainable City X. Urban Regeneration and Sustainability, „WIT Transactions on Ecology and the Environment", 194, Wessex Institute of Technology, WIT Press, Southampton \& Boston: 3-10.

Barełkowski R., Barełkowska K., 2003, Struktura metody planowania przestrzennego P.R.S. - podstawy teoretyczne, [w:] Barełkowski R. (red.), Przestrzeń architektury a przestrzeń kulturowa, Ośrodek Wydawnictw Naukowych, Poznań: 7-22.

Barełkowski R., Barełkowska K., Chlasta L., Wardęski Ł., 2013, Plany ochronne - narzędzie zachowania walorów krajobrazowych, [w:] Barełkowski R. (red.), Harmonizowanie przestrzeni. Perspektywy, studia, interwencje, Wydawnictwo Exemplum, Poznań: 137-147.

Barełkowski R., Wardęski Ł., Wojtyra B., 2016a, Metodologiczne i praktyczne aspekty oceny aktualności studium i planów miejscowych na rzecz kreacji polityki przestrzen$n e j=$ Methodological and Practical Aspects of the Assessment of Validity of Development Study for Creation of Spatial Policy, „Przestrzeń i Forma”, 28, Szczecin: $143-164$.

Barełkowski R., Barełkowska K., Chlasta L., Janusz J., Wardęski Ł., 2016b, Czasoprzestrzeń miasta. FAST: rozpoznanie i planowanie dla zrównoważonego rozwoju, „Przestrzeń i Forma", 25, Szczecin: 151-186.

Borkowski Z.H., 2011, Metoda badania marginalności obszarów wiejskich, „Barometr Regionalny", 3(25): 7-12. 
Brzeziński C., 2013, Wybrane problemy planowania przestrzennego w Polsce, „Acta Universitatis Lodziensis. Folia Oeconomica", 289: 105-114.

Czarnik Z., 2010, Istota i zakres władztwa planistycznego gminy, „Administracja: Teoria, Dydaktyka, Praktyka", 3(20): 5-30.

Górecki J., 2015, Wybrane problemy rozwoju i transformacji rolnictwa, „Problemy Rolnictwa Światowego. Zeszyty Naukowe Szkoły Głównej Gospodarstwa Wiejskiego w Warszawie", 15(XXX), 1/2015: 33-38.

Hajduk S., Baran A., 2013, Planowanie przestrzenne gmin a proces inwestycyjny-zagadnienia problematyczne, „Optimum. Studia Ekonomiczne”, 2/62: 117-129.

Izdebski H., Nielicki A., Zachariasz I., 2007, Zagospodarowanie przestrzenne. Polskie prawo na tle standardów demokratycznego państwa prawego, Raport Sprawne Państwo, Program Ernst \& Young, Warszawa.

Kolipiński B., 2014, Planowanie przestrzenne $w$ Polsce $w$ minionym 25-leciu, „Mazowsze. Studia Regionalne", 15: 109-118.

Kowalik T., 2000, Wspótczesne systemy ekonomiczne. Powstanie, ewolucja, kryzysy, Wydawnictwo Wyższej Szkoły Przedsiębiorczości i Zarządzania im. L. Koźmińskiego, Warszawa.

Kowalik T., 2001, Społeczne aspekty transformacji a rola państwa, „Gospodarka Narodowa", 9: 28-47.

Kowalik T., 2007, Polska transformacja a nurty liberalne, „Ekonomista”, 6: 781-797.

Ministerstwo Infrastruktury i Budownictwa (MIiB), 2016, Problemy $w$ dziedzinie planowania przestrzennego, Materiał informacyjny na posiedzenie Komisji Samorządu Terytorialnego i Polityki Regionalnej w dniu 11 maja 2016 roku, Warszawa.

Najwyższa Izba Kontroli (NIK), 2011, Informacja o wynikach kontroli realizacji zadań $w$ zakresie planowania i zagospodarowania przestrzennego przez organy administracji rządowej i jednostki samorządu terytorialnego, Departament Środowiska, Rolnictwa i Zagospodarowania Przestrzennego, Najwyższa Izba Kontroli, Warszawa.

Najwyższa Izba Kontroli (NIK), 2016, Informacja o wynikach kontroli. System gospodarowania przestrzenia gminy jako dobrem publicznym, Departament Infrastruktury, Najwyższa Izba Kontroli, Warszawa.

Raport o ekonomicznych stratach i społecznych kosztach niekontrolowanej urbanizacji w Polsce, 2013, Instytut Geografii i Przestrzennego Zagospodarowania PAN, Warszawa. Schoemaker P.J.H., 1995, Scenario planning: a tool for strategic thinking, „Sloan Management Review", 36(2), Massachussetts Institute of Technology, Cambridge, Mass: $25-40$.

Szwajdler W. (red.), 2013, Aspekty prawne planowania i zagospodarowania przestrzennego, LEX Wolters Kluwer Polska SA, Warszawa.

Śleszyński P., Komornicki T., Solon J., Więckowski M., 2012, Planowanie przestrzenne w gminach, Instytut Geografii i Przestrzennego Zagospodarowania PAN, Wydawnictwo Akademickie Sedno, Warszawa.

Wojtyra B., 2017, Zasoby lokalne $w$ planowaniu przestrzennym centrum wsi - studium przypadku Rokietnicy, ,Studia Obszarów Wiejskich”, 45: 125-140.

Woźniak M., 2015, Ład przestrzenny jako paradygmat zrównoważonego gospodarowania przestrzenia, „Białostockie Studia Prawnicze”, 18: 167-182. 
Zagóra-Jonszta U., 2017, Polscy ekonomiści o przebiegu i skutkach transformacji, „Studia Ekonomiczne. Zeszyty Naukowe Uniwersytetu Ekonomicznego w Katowicach”, 316: 208-219.

\title{
Akty prawne \\ Ustawa z dnia 27 marca 2003 roku o planowaniu $i$ zagospodarowaniu przestrzennym (Dz.U., 2017, poz. 1073, z późn. zm.). \\ Ustawa z dnia 9 października 2015 roku o rewitalizacji (Dz.U., 2017, poz. 1023, z późn. zm.). \\ PROGRAMMING OF RURAL SPACE SANATION. AUTHOR PLANNING MECHANISMS FOR SUSTAINABLE SHAPING OF RURAL AREAS
}

\begin{abstract}
In the first part of the paper, the authors diagnose problems of spatial planning process in Poland being the result of the implementation of effective law. They identify how practice affected by this law generates land use conditions in the rural space. Common situation is that there is apparent lack of integration of planning and strategic documents affecting spatial policies within one territorial unit (commune) and their execution. This deficiency along with inefficient regulations are exploited and in conjunction with other phenomena like increased and uncontrolled development pressure (e.g. by property owners), particularization of prioritization in issuing administrative decisions related to land use, predatory economy of agricultural land, produce unsatisfactory qualities of the built environment. Also, social participation in spatial planning system is often limited and doesn't meet specific objectives.

In the second part, the authors use case studies in order to propose the method applied, as a part of research and related experiment, to the planning process. This study is immersed in particular, practical experience. The method encompasses: scenario-based approach (as part of the P.R.S. method), monitoring and evaluation of spatial policy in communes, introduction of multi-criteria analyses. These mechanisms allow for allowing to identify and understand the conditions and background of activities for spatial policy and aim to improve planning documents.

In the summary, the authors construct a list of recommendations regarding programming of rural development planning. They emphasize the need for a stronger integration of spatial regulation on different levels of management of planning process. They postulate to amplify the integration of planning documents even if it means some degree of reorientation of initially stipulated hierarchy. One of key issues is the introduction of constant and continuous monitoring of spatial policy, preceding decision-making. The solution could be seen as a multi-criteria assessment of spatial conditions and directions, development studies should be based on. Public participation is depicted also as integrated and permeate community share in decision-making focused on clearly defined objectives, countering the conflicts arising from particularism of inhabitants. Authors attempt to define their interpretation of holistic approach to planning studies and documents using
\end{abstract}


broad perspective, with recognition of necessity to acknowledge the uniqueness of every area or site, resulting in respecting different characteristics by relevant establishing of different planning objectives.

Keywords: spatial planning, rural areas, strategic investment resources, FAST method.

Dr hab. inż. arch. Robert Barełkowski, prof. nadzw. ZUT Zakład Projektowania Zintegrowanego Katedra Projektowania Architektonicznego Wydział Budownictwa i Architektury Zachodniopomorski Uniwersytet Technologiczny e-mail: robert@armageddon.com.pl

Mgr inż. Bartosz Wojtyra Zakład Gospodarki Żywnościowej i Wsi Instytut Geografii Społeczno-Ekonomicznej i Gospodarki Przestrzennej Wydział Nauk Geograficznych i Geologicznych Uniwersytet im. Adama Mickiewicza w Poznaniu e-mail: bwojtyra@amu.edu.pl 